\title{
Muslim Fashion Consumers And Purchasing Decision
}

\author{
Wulan Octaviani1, Rosana Eri Puspita2* \\ ${ }^{1}$ Sharia Economics, Faculty of Economics and Islamic Business, State Islamic Institute, Jalan Tentara \\ Pelajar No. 02 City of Salatiga, 50712, Indonesia \\ ${ }^{2}$ Sharia Business Management, Faculty of Economics and Islamic Business, State Islamic Institute, Jalan \\ Tentara Pelajar No. 02 City of Salatiga, 50712, Indonesia \\ E-mail: rosana.eri.p@iainsalatiga.ac.id
}

Manuscripts entered: 2021-01-30 Manuscripts corrected: 2021-03-12 Manuscripts received: 2021-03-16

\section{ABSTRAK}

Penelitian ini bertujuan untuk mengetahui seberapa besar pengaruh product quality, sales promotion, dan islamic branding pada keputusan pembelian dengan minat beli sebagai variabel intervening pada brand Naisha. Fokus objek penelitian ini adalah customer brand Naisha yang pernah bertransaksi secara online. Adapun metode penelitian yang digunakan yaitu kuantitatif dengan data primer yang diperoleh melalui penyebaran kuisioner. Teknik pengambilan sampel menggunakan purposive sampling dan jumlah responden dalam penelitian ini sebanyak 96 responden. Analisis data yang digunakan meliputi uji instrumen, uji statistik, uji asumsi klasik dan analisis jalur path. Hasil dari penelitian ini menunjukkan bahwa product quality, sales promotion, dan islamic branding secara parsial dan simultan berpengaruh positif dan signifikan terhadap minat beli produk Naisha. Hasil lain menunjukkan bahwa variabel product quality dan sales promotion tidak berpengaruh terhadap keputusan pembelian dan variabel minat beli memiliki pengaruh mediasi terhadap variabel independen lainnya.

Kata kunci: citra merek, kualitas produk, promosi

\section{ABSTRACT}

This study aims to determine how much influence product quality, sales promotion, and Islamic branding have on purchasing decisions with purchase intention as an intervening variable in the Naisha brand. The focus of this research object is the customer of the Naisha brand who has transacted online. The research method used is quantitative, with primary data obtained through distributing questionnaires and interviews. The sampling technique used purposive sampling, and the number of respondents in this study was 96 respondents. The data analysis used includes instrument test, multiple linear regression analysis, statistical test, classical assumption test and path analysis. This study indicates that product quality, sales promotion, and Islamic branding partially and simultaneously positively and significantly affect buying interest in Naisha products. Other results indicate that the variable product quality, sales promotion, and Islamic branding positively and significantly affect purchasing decisions. The purchase intention variable has a mediating effect on other independent variables.

Keywords: brand image, product quality, promotion

Copyright (C) 2018 Islamic Banking Economics Study Program, FAI Majalengka University. All rights reserved. 


\section{INTRODUCTION}

Nowadays, everything is instantaneous in the modern era because of the rapid development of technology and information. No exception trading activities are now getting easier. Before the advent of the internet, transactions between sellers and buyers were carried out. This method was still carried out face-to-face in a place commonly called a market. This situation is different from today. Trading activities are now more comfortable because they can be done anytime and anywhere without making direct contact. It's all because of the internet network that connects sellers and buyers, which is currently called buying and selling online (Sukron, 2019). With the current internet media, consumers can find it easier to find various information about a product they will buy. Consumers can more easily make shopping transactions and of course, save time and costs. Business people must prepare a strategy in handling their customers (Prihartini \& Fauzi, 2020).

Indonesia is one of the dozens of countries with tremendous and promising opportunities for business actors who market their products online, either using social media or e-commerce. This can be seen from the geographical conditions and the people's shopping interest. Not only that, with the current demographic bonus, Indonesians of productive age can become a target market for companies that want to reap profits through these conditions. With the use of the internet, purchasing of goods can now be made through cyberspace. Online sales are now increasingly systemized, and there are more and more enthusiasts in almost all levels of society. Such systems are often called virtual markets(Wulansari, 2015).

In this case, business actors start competing to develop their businesses and create innovations in making products with high competitiveness to attract the public's hearts to decide to buy these products.
Table 1

Internet Content User Data (Commercial)

\begin{tabular}{|c|c|c|}
\hline No & E-Commerce & User (\%) \\
\hline 1 & Shopee & 11,2 \\
\hline 2 & Bukalapak & 8,4 \\
\hline 3 & Lazada & 6,7 \\
\hline 4 & Tokopedia & 4,3 \\
\hline 5 & Traveloka & 2,3 \\
\hline 6 & OLX & 0,6 \\
\hline 7 & Gojek & 0,5 \\
\hline 8 & Gramedia & 0,1 \\
\hline 9 & Amazon & 0,1 \\
\hline 10 & Blibli & 0,1 \\
\hline 11 & Alibaba & 0,1 \\
\hline 12 & Other & 3,3 \\
\hline
\end{tabular}

Source: APJII (2018) Data processing

According to data obtained from APJII 2018 in Table 1.1, it shows that the majority of Indonesians have a high enough interest in making purchases online, both through e-commerce and social media. Several service providers are buying and selling online in the table so that Indonesians have many places to make transactions. It can be concluded that most people are more likely to be interested in purchasing products online than directly.

Fashionist creative idea has a dominant role in contributing to the country's economy. The fashion industry has now turned into a locomotive in the development stage of the national creative industry. In 2009, a Presidential Instruction (Inpres) Number 6 of 2009 was issued by the Ministry of Industry through the Directorate General of Small and Medium Industries (IKM), regarding Creative Economy Development as a basis for all stakeholders in developing 14 creative economy sectors. Of the 14 industries, several sub-sectors fall under the scope of guidance of the Ministry of Industry, which include crafts, fashion, computers, and software (Presidential Instruction of the Republic of Indonesia No. 6 of 2009, 2009).

One fashion area experiencing an increase is fashion that focuses on designs for Muslim clothing (Istiani, 2015). People's interest in wearing Muslim dress is getting higher, and it causes the demand to increase. Conditions like this allow Muslim clothing designer entrepreneurs to make quality products 
with high competitiveness but still syar'i, such as robes and hijabs(Achyar, 2015). In addition to being a necessity, Muslim clothing has now turned into a trend among teenagers to homemakers. This condition creates an opportunity for companies to compete in creating various Muslim clothing styles popular with the community. One of a company's strategies to win a market competition is by providing satisfaction to its consumers; this strategy can be carried out by delivering products and services of good quality to have high competitiveness. By implementing this, it is hoped that consumers will be interested in, and the demand for these products will increase(Agustiyo, 2016).

Another important aspect to five a consumer impression is sales promotion. Through sales promotion, a company will find it easier to introduce its products. Sales promotion can be defined as a set of incentive and mostly short-term tools, then designed to attract consumers so that consumers decide to buy products and services offered by companies on a larger and faster scale (Kotler \& Keller, 2016).

Indonesia is one of the dozens of countries included in countries with the largest Muslim population globally. Immigrants in Indonesia have very high potential, especially entrepreneurs who market their products through e-commerce or social media. Entrepreneurs in Indonesia certainly understand that Indonesian consumers, predominantly Muslim, can be their target market. One of the tricks and strategies to captivate the hearts of Indonesians is Islamic branding. What is said to be Islamic branding is the use of a name attached to a product which has an attachment to Islam or in other words it can show the halal identity of a certain product (Rif'adah, 2019).

This research was conducted because nowadays, many companies are involved in the competition in the world of trade, especially companies that focus on Muslim clothing. This condition is made clear by the significant increase in Muslim fashion (Istiani, 2015). The high interest of Muslims in wearing Muslim clothing makes this opportunity captured by many businessmen.

Therefore this research was conducted on one of the Muslim fashion brands, namely Naisha. Naisha is a Muslim fashion producer who is experienced in providing the needs of Muslim women. Although Naisha is still a brand that has not been in the fashion world for a long time, it has advantages over other brands. In terms of products, Naisha has more than 30 varied products, not only that, once every three weeks, Naisha launches its newest product, it is one trick to keep up with current trends.

Then, in marketing its products, Naisha has entered several market space and social media platforms such as Website, Shopee, Lazada, Tokopedia, Bukalapak, Instagram, and Facebook, in contrast to other brands that only focus on one ecommerce. On the other hand, Naisha also collaborates with resellers throughout Indonesia. Since its establishment two years ago, Naisha has managed to have 4,000 resellers, which is why this Naisha brand is superior even though it is relatively young. Naisha also has a wide enough target market so that its products are easily recognized and attract the public's hearts. Thus, to develop a business, innovative market strategies are needed, and it is hoped that the products sold will be even higher.

This study aims to determine how much influence product quality, sales promotion and Islamic branding have on purchasing decisions with purchase intention as an intervening variable in the Naisha brand. Through this study's results, it is hoped that it can be used as a benchmark for the company to determine the strategy taken so that the products to be marketed have more value in consumers' eyes.

\section{METHOD}

This research object is the Naisha brandcustomer who has made online purchase transactions through e-commerce and social media. The research method used is a quantitative research using data in the form of numbers and statistics. The data taken in this study are primary data obtained by distributing questionnaires to related parties.

In this study, instrument testing used validity and reliability tests. The validity test is used to determine how strong the measuring instrument used in carrying out its function is what is being measured in the questionnaire. Indicators can be declared valid if the value of 2-star Person Correlation $\left({ }^{* *}\right)$ with a significance value at the 0.05 level. While the reliability test is a test conducted to measure a variable's indicator, the reliability test is based on the Cronbach alpha value. A variable can 
be said to be reliable if the Cronbach alpha value is $>$ 0.70 .

Table 2

Validity Test Results

\begin{tabular}{|c|c|c|c|c|}
\hline No & Variabel & Item & $\begin{array}{l}\text { Total Score } \\
\text { Correlation }\end{array}$ & Information \\
\hline \multirow[t]{10}{*}{1} & \multirow[t]{10}{*}{ Prodict Quality (X1) } & Item 1 & $0,648\left({ }^{* *}\right)$ & Valid \\
\hline & & Item 2 & $0,650(*)$ & Valid \\
\hline & & Item 3 & $0,633\left({ }^{\circ}\right)$ & Valid \\
\hline & & Item 4 & $0,324(* *)$ & Valid \\
\hline & & Item 5 & $0,340(* *)$ & Valid \\
\hline & & Item 6 & $0,793\left({ }^{* *}\right)$ & Valid \\
\hline & & Item 7 & $0,444\left(^{\circ+}\right)$ & Valid \\
\hline & & Item 8 & $0,473\left({ }^{* *}\right)$ & Valid \\
\hline & & Item 9 & $0,476(* *)$ & Valid \\
\hline & & Item 10 & $0,294\left({ }^{* *}\right)$ & Valid \\
\hline \multirow[t]{5}{*}{2} & \multirow[t]{3}{*}{ Sales Promotion (X2) } & Item 1 & $0,792\left({ }^{\circ}\right)$ & Valid \\
\hline & & Item 2 & $0,768\left({ }^{* *}\right)$ & Valid \\
\hline & & Item 3 & $0,842\left(^{* *}\right)$ & Valid \\
\hline & & Item 4 & $0,761(* *)$ & Valid \\
\hline & & Item 5 & $0,726\left({ }^{\circ}\right)$ & Vaild \\
\hline \multirow[t]{4}{*}{3} & \multirow[t]{4}{*}{ Islamic Branding (X3) } & Item 1 & $0,689(* *)$ & Valid \\
\hline & & Item 2 & $0,766\left({ }^{* *}\right)$ & Valid \\
\hline & & Item 3 & $0,702\left({ }^{*}\right)$ & Valid \\
\hline & & Item 4 & $0,720(* *)$ & Valid \\
\hline \multirow[t]{4}{*}{4} & \multirow[t]{4}{*}{ Intention To Big (Z) } & Item 1 & $0,897\left({ }^{\circ *}\right)$ & Vaild \\
\hline & & Item 2 & $0,854\left({ }^{* *}\right)$ & Valid \\
\hline & & Item 3 & $0,795\left({ }^{* *}\right)$ & Vaild \\
\hline & & Irem 4 & $0,866\left({ }^{\circ *}\right)$ & Valid \\
\hline \multirow[t]{4}{*}{5} & \multirow[t]{4}{*}{ Buying Decision $(Y)$} & Item 1 & $0,847\left({ }^{* *}\right)$ & Vaild \\
\hline & & Item 2 & $0,836\left({ }^{* *}\right)$ & Vaild \\
\hline & & Item 3 & $0,830(* *)$ & Valid \\
\hline & & Item 4 & $0,856\left({ }^{* *}\right)$ & Valid \\
\hline
\end{tabular}

Source: Primary Data Processed, 2020

Based on the table of validity test results, it can be seen that all variable indicators in this study have two stars $\left({ }^{* *}\right)$ at a significance level of 0.05 so that the questions submitted are valid and no items are deleted.

Table 3

Reliability Test Results

\begin{tabular}{|l|l|l|}
\hline \multicolumn{1}{|c|}{ Variabel } & Cronbach's Alpha & \multicolumn{1}{c|}{ Information } \\
\hline Product Quality (X1) & 0,777 & Reilable \\
\hline Sales Promotion (X2) & 0,836 & Reliable \\
\hline Islamic Branding (X3) & 0,701 & Reliable \\
\hline Intention To Biy (Z) & 0,875 & Reliable \\
\hline Biving Decision (Y) & 0,861 & Reilable \\
\hline
\end{tabular}

Source: Primary Data Processed, 2020

Based on the reliability test, it states that each variable has a Cronbach alpha value $>0.70$. It can be concluded that the variable product quality, sales promotion, Islamic branding, purchase interest and purchase decisions are said to be reliable.

Meanwhile, the chosen population is the online customer of the Naisha brand that is spread across Indonesia. Sampling technique using purposive random sampling. It is meant by purposive random sampling, is selecting samples based on certain characteristics or traits that are considered to have a close relationship with the characteristics or characteristics of the population that have been previously known (Riyanto \& Hatmawan, 2020). In this study, 96 respondents used the Naisha brand customer in Java and used the Likert scale for operational variables. In analyzing the data, the authors used the SPSS application through the instrument test stage, statistical tests, classical assumption tests and path analysis.

The operational definition of the variables in this study includes product quality, sales promotion, Islamic branding, purchase interest and purchase decisions. Product quality can be defined as a product's ability to carry out its functions and benefits, including durability, reliability, reliability, ease of operation and repair, and other valuable attributes(Kotler and Armstrong, 2013). Then sales promotion consists of short-term incentives to encourage a purchase or sale of a product or service. There are several tools to encourage and maximize the sales promotion strategy (Kotler, P. \& Armstrong, 2008). Furthermore, Islamic branding uses names where these names are related to Islam or can show a halal identity in a certain product.(Jumani \& Siddiqui, 2012). Next is buying interest, something created after someone gets stimulated from a product they see, from these observations there is an attraction to try, and in the end, the consumer wants and tries to have and then buy it (Kotler, 2005). Finally, the definition of a purchasing decision is a process of encouragement from within a person who is influenced by several internal and external factors that cause a person to decide on a product (Alma, 2018).

\section{RESULTS AND DISCUSSION}

This study conducted a classical assumption test. This test is the multicollinearity test, heteroscedasticity test and normality test.

The multicollinearity test is a test conducted to determine whether there is a correlation between the regression model's independent variables. Decision making in the multicollinearity test can be seen from the VIF value $<10$. In this study, all variables have a VIF value $<10$ so that there are no multicollinearity symptoms. 
Meanwhile, the heteroscedasticity test is a test carried out to see whether the regression model has a similar variance from the residuals from one observation to another. A good regression model is homoscedasticity, or heteroscedasticity does not occur. If the significance probability $>0.05$, it can be concluded that heteroscedasticity does not happen. Variable product quality with sig 0.148 , sales promotion sig 0.974 , Islamic branding sig 0.834, and buying interest sig 0.741 . It can be concluded that all variables have a sig value> 0.05 there is no heteroscedasticity symptom.

Then a normality test was conducted to determine whether the residual variables were normally distributed or not. This test was carried out by looking at the significance value of Asymp.Sig (2-tailed) if the value $\alpha \geq 0.05$, it can be concluded that it has a normal distribution. In this study, the Asymp.Sig (2tailed) value was $0.467>0.05$, so it was said that the residual value was normally distributed.

Table 4

Result of T-Test Model 1

\begin{tabular}{|l|l|l|l|}
\hline \multicolumn{1}{|c|}{ Model } & \multicolumn{1}{c|}{ B } & \multicolumn{1}{c|}{ T } & \multicolumn{1}{c|}{ Sig. } \\
\hline Product Quality & 0,175 & 2,255 & 0,026 \\
\hline Sales Promotion & 0,240 & 2,2371 & 0,020 \\
\hline Islamic Branding & 0,439 & 3,255 & 0,002 \\
\hline
\end{tabular}

Source: Primary Data Processed, 2020

After performing the classical assumption test, statistical testing or hypothesis testing is carried out. The first hypothesis is about the effect of product quality on buying interest in Naisha products. It can be done by looking at the significant value in Table 3.1 to determine the effect of the variable product quality on purchase intention. The table shows the sig product quality value of $0.026<0.05$, so it can be concluded that product quality has a positive and significant effect on buying interest in Naisha's products. This is supported by previous research that states that product quality positively and significantly affects purchase intention(Arianto \& Difa, 2020). Consumers assume that if a product has good quality and quality, these consumers will tend to be interested in buying it to make any efforts to have the product they want.
Then about the effect of sales promotion on buying interest in Naisha products. Table 3.1 shows the significant value of sales promotion of $0.020<0.05$, so it can be concluded that the sales promotion variable has a positive and significant influence on Naisha's products' purchase interest. Previous research supports these results, which states that sales promotions significantly affect purchase intention(Satria, 2017).

In this case, when sales promotions within a company are functioning properly and on target, consumers will be more familiar with the company's products. Consumers will be more interested in buying these products through sales promotions in attractive ways such as giving discounts, bonuses, and gifts.

Furthermore, the results showed the effect of Islamic branding on buying interest in Naisha products. Table 3.1 stated that the Islamic branding variable's significance value is 0.002 $<0.05$, so it can be concluded that the Islamic branding variable has a positive and significant effect on buying interest in Naisha products. Previous research supports these results, stating that Islamic branding has a positive and significant effect on consumer buying interest(Siti Khadijah, 2020). This means that the brand image of Islam greatly influences consumers in choosing a product they will buy. The more the product has a strong brand image, the more consumers will trust the product than the product that does not yet have a brand image. With the existence of Islamic branding attached to a product, consumers are expected to be more interested in buying the products that the company issues.

Table 5

\section{Result of T-Test Model 2}

\begin{tabular}{|l|l|l|l|}
\hline \multicolumn{1}{|c|}{ Model } & \multicolumn{1}{|c|}{ B } & \multicolumn{1}{c|}{ T } & \multicolumn{1}{c|}{ Sig. } \\
\hline Prodict Quality & 0,111 & 2,024 & 0,046 \\
\hline Sales Promotion & 0,009 & 0,120 & 0,905 \\
\hline Islamic Branding & 0,058 & 0,590 & 0,557 \\
\hline Intention To Bly & 0,694 & 9,652 & 0,000 \\
\hline
\end{tabular}

Source: Primary Data Processed, 2020

Furthermore, in the model 2 hypothesis test about the effect of product quality on purchasing decisions for Naisha products, the significance value of product quality is 0.046 $<0.05$. It can be concluded that the product 
quality variable has a positive and significant effect on purchasing decisions for Naisha products. These results are supported in research which states that product quality has a significant positive effect on purchasing decisions (Amilia, 2017). In this case, consumers tend to make purchases of the right quality products so that companies need to pay attention to the quality of the products they issue to maintain and maintain consumer loyalty.

Then the results of the effect of sales promotion on purchasing decisions for Naisha products. Based on Table 3.4, it can be seen that the significant value of sales promotion is $0.905>0.05$, which means that sales promotion does not have a significant effect on purchasing decisions on Naisha products. This study's results are supported by previous research that states that sales promotions do not substantially affect buying decisions (Arifin \& Fachrodji, 2015).

Promotion variable has five dimensions, namely Advertising, Sales Promotion, Public Relations, Direct Marketing and Personal Selling. Of the five dimensions, it cannot simultaneously have an equally strong influence on purchasing decisions. Different types of products will certainly differ in the strength of the relationship from each of these dimensions. When a company carries out a sales promotion, it will not fully influence consumers in making buying decisions. It could be that these consumers only see advertisements that appear without any encouragement to purchase products.

The results regarding the effect of Islamic branding on purchasing decisions for Naisha products from Table 3.2 show that the significance value of Islamic branding is $0.557>$ 0.05 , which means that the Islamic branding variable does not significantly affect purchasing decisions for Naisha products. These results are supported by research that states that Islamic branding does not significantly affect purchasing decisions (Sumeyra Duman, 2013). This means that the ideals of Islamic brands do not influence consumers in making purchasing decisions. Consumers will still make purchases of a product if the product is superior in other ways such as quality, price, etc. even though the brand attached to the product is not well known.

After statistical testing was carried out, this study also carried out the path analysis test. This test is conducted to analyze the causal relationship between variables to determine the direct and indirect effect, either simultaneously or individually, several causal variables on an effect variable.

\section{Figure 1}

Path Analysis Chart

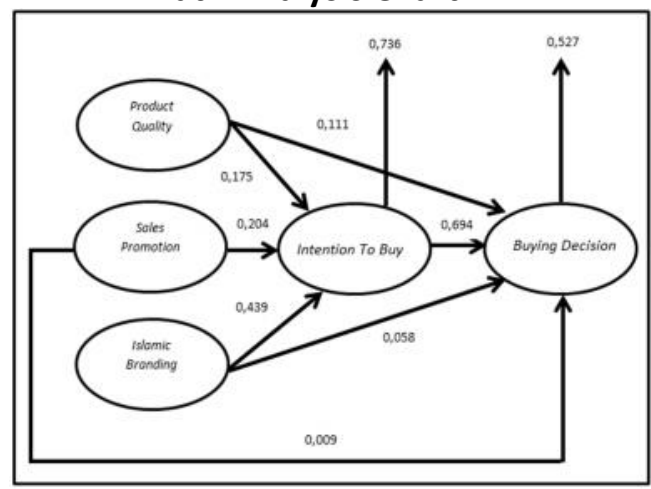

This test is conducted to determine the effect of product quality, sales promotion, and Islamic branding on purchasing decisions with purchase intention as an intervening variable. The first result is that the direct effect of the product quality variable on the interest variable is 0.175 , while the indirect effect must be calculated, namely $(0.175 \times 0.694)=0.1214$. With the total effect $(0.111+0.1214)=0.2324$. The $t$ value is $2.2525>t$ table 1.66177 , so it can be concluded that product quality affects purchasing decisions with purchase intention as an intervening variable.

The magnitude of the direct influence of the sales promotion variable on the purchase interest variable is 0.204 , while the indirect effect must be calculated, namely $(0.240 \mathrm{x}$ $0.694)=0.1665$. With the total effect $(0.009+$ $0.1665)=0.1755$. The $t$ value is $2.3125>t$ table 1.66177 , so it can be concluded that sales promotion affects purchasing decisions with purchase intention as an intervening variable.

Furthermore, the Islamic branding variable's direct influence on the purchase intention variable is 0.439 , while the indirect effect must be calculated, namely $(0.439 \mathrm{x}$ $0.694)=0.3046$. With the total effect $(0.058+$ $0.3046)=0.3626$. The $t$ value is $2.9601>t$ table 1.66177 , so it can be concluded that Islamic 
Maro; Jurnal Ekonomi Syariah dan Bisnis

E-ISSN: 2621-5012 P-ISSN: 2655-822X

branding has an effect on purchasing decisions through purchase intention as an intervening variable.

\section{CONCLUSION}

This study concludes that the variable product quality, sales promotion, and Islamic branding influence buying interest in Naisha products. Then the other results show that the variable product quality influences purchasing decisions of Naisha products. In contrast, the variables of sales promotion and Islamic branding do not significantly influence the purchasing decisions of Naisha products. Furthermore, the purchase intention variable in this study can be a mediation so that the conclusion is that the variable product quality, sales promotion and Islamic branding have an effect on purchasing decisions with purchase intention as an intervening variable.

\section{SUGGESTION}

After tested variable of product quality, sales promotion, and Islamic branding on the Naisha brand, the authors provide suggestions. The author suggests to Naisha Brand to further improve product quality and strengthen the brand image they have so that consumers are more satisfied and trust the products released by Naisha to improve consumer loyalty to the Naisha brand.

\section{REFERENCES}

Achyar, M. (2015). Islamic Philanthropy Sebagai Upaya Mewujudkan Masyarakat Indonesia yang Madani. Kompasiana.

Agustiyo, H. (2016). Pengaruh Kualitas Pelayanan, Kelengkapan Produk dan Kualitas Produk Terhadap Minat Beli Konsumen Supermarket Top Bangunan Kediri. 1-8.

Alma, B. (2018). Pemasaran dan Pemasaran Jasa. In Pemasaran dan Pemasaran Jasa.

AMILIA, S. (2017). Pengaruh Citra Merek, Harga, dan Kualitas Produk terhadap Keputusan Pembelian Handphone Merek Xiaomi di Kota Langsa. Jurnal Manajemen Dan Keuangan Unsam.

Arianto, N., \& Difa, S. A. (2020). Pengaruh Kualitas Pelayanan Dan Kualitas Produk Terhadap Minat Beli Konsumen Pada PT Nirwana Gemilang Property. Jurnal Disrupsi Bisnis : Jurnal Ilmiah Prodi Manajemen, Fakultas Ekonomi, Universitas
Pamulang. https://doi.org/10.32493/drb.v3i2.6299

Arifin, E., \& Fachrodji, A. (2015). Pengaruh Persepsi

Kualitas Produk, Citra Merek Dan Promosi

Terhadap Minat Beli Konsumen Ban Achilles Di Jakarta Selatan. Jurnal MIX.

Instruksi Presiden Republik Indnesia No 6 Tahun 2009. (2009). Instruksi Presiden Republik Indnesia No 6 Tahun 2009 Tentang Pengembangan Ekonomi Kreatif. Ekp.

Istiani, A. N. (2015). Konstruksi Makna Hijab Fashion Bagi Moslem Fashion Blogger. Jurnal Kajian Komunikasi, 3(1), 48-55. https://doi.org/10.24198/jkk.vol3n1.6

Istiani, A. N. (2015). KONSTRUKSI MAKNA HIJAB FASHION BAGI MOSLEM FASHION BLOGGER. Jurnal Kajian Komunikasi.

https://doi.org/10.24198/jkk.v3i1.7393

Jumani \& Siddiqui. (2012). BASES OF ISLAMIC BRANDING IN PAKISTAN: PERCEPTIONS OR BELIEVES. Interdisciplinary Journal of Contemporary Research in Business.

Kotler, P. \& Armstrong, G. (2008). Prinsip-Prinsip Pemasaran. Edisi 12. Jilid 1. Manajemen Pemasaran.

Kotler. (2005). Manajemen Pemasaran. In: Manajemen Pemasaran. In Edisi Millenium, Jilid 1.

Kotler dan Amstrong. (2013). Prinsip-Prinsip Pemasaran Jilid I. In Erlangga.

Kotler, P., \& Keller, K. L. (2016). Marketing Mangement. In Pearson Edition Limited.

Prihartini, E., \& Fauzi, H. (2020). Pengaruh Social Media Marketing , Brand Awareness dan Word Of Mouth Terhadap Minat Beli Smartphone Samsung ( Studi pada Mahasiswa Universitas Majalengka ) Pengaruh Social Media Marketing , Brand Awareness dan Word of Mouth Terhadap Minat Beli Smartphone S. 3(2), 138-147.

Rif'adah, Y. (2019). Pengaruh Islamic Endorsement dan Islamic Branding terhadap minat beli di media sosial Instagram Safi Indonesia.

Riyanto, S., \& Hatmawan, A. A. (2020). Metode Riset Penelitian Kuantitatif Penelitian Di Bidang Manajemen, Teknik, Pendidikan Dan Eksperimen. In Metode Riset Penelitian Kuantitatif Penelitian Di Bidang Manajemen, Teknik, Pendidikan Dan Eksperimen.

Rony, A., \& Sukron, M. (2019). Pengaruh Kemudahan Penggunaan, Islamic Branding dan E-Service Quality Terhadap Keputusan Pembelian di Tokopedia Dengan Minat Beli Sebagai Variabel Intervening SKRIPSI Diajukan Untuk Memenuhi dan Melengkapi Syarat Kelulusan Guna Memperoleh Gelar Sarjana Ek

Satria, A. A. (2017). Pengaruh Harga, Promosi, dan Kualitas Produk Terhadap Minat Beli Konsumen Pada Perusahaan a-36. Jurnal Manajemen Dan Start-Up Bisnis. 
Siti Khadijah, O. A. W. (2020). Islamic Branding Restoran Korea Terhadap Minat Beli Konsumen. Jurnal Makna.

Sumeyra Duman, K. (2013). Purchasing Behavior of Islamic Brands : An Experimental Research. 42 Annual Conference European Marketing Academy. Wulansari, D. A. (2015). PENGARUH PENJUALAN ONLINE TERHADAP OMZET PENJUALAN BUTIK ZIETA DESA SEWULAN KEC. DAGANGAN KAB. MADIUN. EQUILIBRIUM : Jurnal Ilmiah Ekonomi Dan Pembelajarannya.

https://doi.org/10.25273/equilibrium.v3i2.664 